\title{
Accounting
}

\section{Concentration and performance in Vietnamese commercial banks}

\author{
Hung Cuong Le ${ }^{a}$ and Tien Loc Vo ${ }^{b^{*}}$
}

\author{
${ }^{a}$ Nam A Bank, Ho Chi Minh City, Vietnam

\section{H R O N I C L E} \\ Article history: \\ Received September 12019 \\ Received in revised format \\ September 32019 \\ Accepted October 232019 \\ Available online \\ October 232019 \\ Keywords: \\ Vietnamese banking sector \\ Concentration ratio \\ Herfindahl-Hirschman index \\ Panzar-Rosse model
}

${ }^{b}$ Thai Son Olympus Company Limited, Ho Chi Minh City, Vietnam

\section{A B S T R A C T}

The paper examines the effect of concentration on performance in the Vietnamese commercial banks during the period 2005-2012, using the concentration ratio and the Herfindahl-Hirschman index to measure the level of concentration in the banking sector. We find a clear trend of decreasing concentration of the Vietnamese banking sector over the analyzed period, along with an increase in competition. The results of the competitive analysis based on The Panzar-Rosse model show a status of monopoly competition market has formed in the banking sector. With respect to the effects of concentration on banks' performance, the study finds a negative relationship between the concentration of the market and operational performance of the commercial banks in the context of monopoly competition. We conclude that high competition and less concentration stimulate the banking sector to achieve a more balanced allocation of credits and promoting sustainable economic growth.

(C) 2020 by the authors; licensee Growing Science, Canada

\section{Introduction}

The market power model can be divided into two groups. The first group consists of structural models, the second group includes models in the reduced form. Important models in the structural model group include the Monti-Klein model (Klein, 1971) for monopoly competition and the Salop model (Salop, 1979) which deals with spatial competition. These models, along with new industrial organization models (NEIO), have been available since accurate and direct measurements of market power. However, the application of these models in empirical studies is still relatively rare due to data and estimation problems that prevent appropriate statistical tests. Reduced model is a better simulation of market power. This model became popular in research, led by the Structure - Conduct - Performance (SCP) model and more recently the Panzar-Rosse model. Within the group of simplified models, two different subgroups are distinguished: price-based models and models based on variables that represent market power. Input price is the most prominent feature in the Panzar-Rosse model, in which the competition measure $(\mathrm{H})$ is defined as the sum of the elasticities of revenues with respect to price factors. An estimated value of $\mathrm{H}$ equal to 1 means perfect competition. $\mathrm{H}$ with a value between 0 and 1 indicates monopolistic competition status, and $\mathrm{H}$ less than 0 indicating monopoly market status. In fact, due to very rare and unreliable pricing information in the banking market, the Panzar-Rosse model is limited in application. In addition, this model ignores product differentiation, and it assumes a long-term equilibrium, zero returns in the market, and a flat marginal cost curve. In general, the Panzar-Rosse model has its advantages, but it is quite ideal for market power testing in the banking market since it depends on price information.

* Corresponding author.

E-mail address: votienloc1202@gmail.com (T.L. Vo) 
The most common simplified model that does not require price information is the SCP model. The SCP model can model any form and scale of market power that affects the operational efficiency of banks through the structure. In addition, the SCP model can incorporate nonlinear average cost curves (which have been shown to exist in the banking sector, see Molyneux, Altunbas, and Gardener (1997)). On the other hand, this type of model provides relatively convenient measures for market power. A review of international studies shows that, in general, international studies have only shown that market power affects banks' operational performance. However, up to now, according to the author's best knowledge, there has not been an in-depth study to consider the impact of market power on the operational performance of commercial banks in Vietnam. Our paper, therefore, extends the existing knowledge about crucial parameters of the banking industry. Moreover, by employing the methodology mostly used in international as well as national analysis of banking concentration and competition, the results on the Vietnamese banking sector are easily comparable with findings of other similar studies.

The aim of this paper is to examine the degree to which the concentration affect performance in Vietnamese commercial banks during the period 2005-2012. We analyze competition and concentration after year 2005 when the new Enterprises Act and Competition Law has been implemented by the Vietnamese government. We use the concentration ratio and the HerfindahlHirschman index to estimate the degree of concentration of the Vietnamese banking industry and its effects on performance in commercial banks. The structure of this paper is as follows. After the introduction, the second section describes methods and data used in the paper and the third section overviews the concentration of the Vietnamese banking sector. The fourth section presents empirical results and discussion. The last section concludes.

\section{Methods and data}

\subsection{Econometric models}

\subsubsection{Model specification: concentration of Vietnamese banking sector}

The paper starts from the SCP model and Gajurel and Pradhan (2012) to develop a price-based econometric model to identify the concentration of the banking market. The model is as follows:

$$
\operatorname{lnREVN_{it}}=a+b_{1} \operatorname{lnINTC}_{i t}+b_{2} \ln N O N_{-} I N T_{-} E X P E N S E_{i t}+b_{3} L O A N_{i t}+b_{4} \ln T A_{i t}+b_{5} E Q U I T Y_{i t}+u_{i}+e_{i t}
$$

where

- $\quad \ln R E V N$ is total interest revenue (in logarithm form).

- $\quad \ln I N T C$ is the total interest expenses (in logarithm form).

- $\quad$ InNON_INT_EXPENSE is total other operating expenses (in logarithm form).

- $\quad L O A N \overline{\text { is }}$ the ratio of total loans to total assets.

- $\quad \ln T A$ is total assets (in logarithm form).

- $\quad E Q U I T Y$ is the ratio of equity to total assets;

- $\quad u$ is the bank-specific characteristic effect.

- $\quad e$ is the error terms, including time-variance effects.

The first three independent variables are prices of inputs such as funding, labor and capital; the remaining three independent variables are control variables of the bank characteristics. Because the Panzar and Rosse models have a log-linear form, the sum of the price-weighting coefficients of the inputs is considered "H-statistic". We regress the concentration model 1, using methods of Pooled Ordinary Least Squared Regression (OLS), Fixed-effects panel model (FEM) and Random-effects panel model (REM).

\subsubsection{Model specification: effects of competition on performance in Vietnamese commercial banks}

The paper starts from the SCP model (Model 2) and Gajurel and Pradhan (2012) to develop a price-based econometric model to identify the effect of competition on commercial banks' performance of the in Vietnam. The model is as follows:

$$
\operatorname{lnREVN} N_{i t}=a+b_{1} L O A N_{i t}+b_{2} \operatorname{lnT} A_{i t}++b_{3} E Q U T Y_{i t}+b_{4} \text { MARKET }_{i t}+b_{5} H H I_{-} C R 35_{i t}+u_{i}+e_{i t}
$$

where,

- $\quad \ln R E V N$ is total interest revenue (in logarithm form).

- $\quad \ln I N T C$ is the total interest expenses (in logarithm form).

- $\quad$ InNON_INT_EXPENSE is total other operating expenses (in logarithm form).

- $\quad L O A N \overline{\text { is }}$ the ratio of total loans to total assets. 
- $\quad \ln T A$ is total assets (in logarithm form).

- EQUITY is the ratio of equity to total assets;

- HHI_CR35 is the Herfindahl-Hirschman index, and the concentration ratio (namely: CR3 and CR5).

The concentration ratio $(C R)$ shows the degree to which an industry is dominated by a small number of large firms. For example: CR3 and CR5 are the total share of the three (and five) largest firms in the industry, respectively. It has been frequently used in empirical studies as proxies for concentration of any kind of industry. The Herfindahl-Hirschman index is the measure of concentration. Bikker and Haaf (2002) defined $H H I$ as the sum of the squares of the bank sizes measured as market shares. It takes the following form:

$$
H H I=\sum_{k=1}^{n}\left(\frac{q_{k}}{Q}\right)^{2}=\sum_{k=1}^{n} r_{k}^{2}
$$

where $n$ is the number of banks in the banking sector, $q_{k}$ is the volume of the output of the bank $k, k=1,2, \ldots, \mathrm{n}, Q$ is the volume of the output of the banking sector and $r_{k}$ is the share of the output of the bank $k$ to the output of the banking sector. The $H H I$ index ranges between 0.01 and 1.0. In practice, the value of the $H H I$ is multiplied by 10000 and then $H H I$ indices below 1000 show a very low concentration, between 1000 and 1800 show a moderate concentration, above 1800 show a very high concentration of the banking system, whereas the index equal to 10000 shows a full concentration (monopoly).

Model 2A: The market power variable is measured by the following indicators: (1) The value of a bank's deposits over total value of deposits of commercial banks, (2) The value of total assets of a bank banks in total assets of commercial banks, (3) The value of loans of a bank in total value of loans of commercial banks; and the market concentration index is measured by HHI of (1) banks' deposits, (2) banks' total assets, (3) banks' loans;

Model 2B: The market power variable is measured by the following indicators: (1) The value of a bank's deposits over total value of deposits of commercial banks, (2) Value of total assets of a bank banks in total assets of commercial banks, (3) The value of loans of a bank in total value of loans of commercial banks; and the market concentration index is measured by CR3 of (1) banks' deposits, (2) banks' total assets, (3) banks' loans;

Model 2C: The market power variable is measured by the following indicators: (1) Deposits value of a bank in total deposits of commercial banks, (2) Value of total assets of a bank banks over total assets of commercial banks, (3) The value of loans of a bank in total value of loans of commercial banks; and the market concentration index is measured by CR5 of (1) banks' deposits,

(2) banks' total assets, (3) banks' loan.

- $\quad \mathrm{u}$ is the bank-specific characteristic effect.

- $\quad$ e is the error terms, including time-variance effects.

\subsection{Data}

The dataset used in the current paper is from the BankScope, which is a comprehensive, comprehensive global database containing state-owned and private banking information. The main dataset is a collection of 44 banks, from 2005 to 2012. The data have a structure in the form of unbalanced panel data from 1998 to 2012. Among 44 commercial banks in the sample with 195 observations, there are six large scale ones with chartered capital of over VND 10,000 billion, seven medium-sized banks (chartered capital from VND 5,000 billion to less than VND 10,000 billion) and 22 small-scale banks (charter capital of less than VND 5,000 billion). In addition, there are seven foreign commercial banks, joint venture banks or branches of foreign commercial banks. From the main data with 44 banks mentioned above, the paper comes to a final set of data including 37 banks with 168 observations of Vietnam commercial banks, from 2005 to 2012 (the number of observations decreases because some banks do not have enough information for some variables in the model).

\section{Overview of concentration of the Vietnamese banking sector}

The level of competition in the banking sector is increasingly fierce through the market structure with changes in the number of banks and changes in market share. Table 1 presents the CR3 and CR5 concentration indices of the top 3 and 5 banks in the sample, respectively. The CR3 index for deposits has decreased from $63 \%$ in 2005 to $44 \%$ in 2012 , a decrease of about one third of percentage points. Similarly, the CR3 concentration index for assets has also decreased from 63\% in 2005 to $42 \%$ in 2012 . CR3 for loans tends to decrease similarly but more slowly. The CR5 for deposits has decreased from $84 \%$ in 2005 to $56 \%$ in 2012 , down by a third of percentage points. Similarly, the CR5 concentration index for assets is also decreased from $82 \%$ in 2005 to $53 \%$ in 2012. CR5 for loans tended to decrease similarly but more slowly. The fact that the concentration indexes decreased rapidly over the years reflects the structure of the banking market. In addition, the rapid change in CR3 compared with CR5 implies the emergence and the formation of many new influential banks in the banking industry. In summary, the 
period 2005-2012 shows that the Vietnamese banking market has shifted from a highly concentrated market (reflected in CR3 indices greater than 65\%), and monopoly into a market with average concentration level and high competitiveness.

Table 1

Concentration (CR3, CR5) of Vietnamese banking sector, 2005-2012

\begin{tabular}{|c|c|c|c|c|c|c|c|}
\hline \multirow[t]{2}{*}{ Year } & \multirow[t]{2}{*}{ Number of banks } & \multicolumn{2}{|c|}{ Deposits } & \multicolumn{2}{|c|}{ Assets } & \multicolumn{2}{|c|}{ Loans } \\
\hline & & CR3 & CR5 & CR3 & CR5 & CR3 & CR5 \\
\hline 2005 & 27 & 0.63 & 0.84 & 0.63 & 0.82 & 0.67 & 0.84 \\
\hline 2006 & 33 & 0.60 & 0.79 & 0.58 & 0.76 & 0.61 & 0.78 \\
\hline 2007 & 35 & 0.53 & 0.70 & 0.48 & 0.65 & 0.55 & 0.70 \\
\hline 2008 & 36 & 0.54 & 0.70 & 0.49 & 0.66 & 0.56 & 0.71 \\
\hline 2009 & 43 & 0.45 & 0.60 & 0.41 & 0.58 & 0.49 & 0.64 \\
\hline 2010 & 40 & 0.42 & 0.58 & 0.37 & 0.52 & 0.49 & 0.62 \\
\hline 2011 & 38 & 0.42 & 0.59 & 0.36 & 0.53 & 0.48 & 0.63 \\
\hline 2012 & 31 & 0.44 & 0.56 & 0.42 & 0.53 & 0.50 & 0.60 \\
\hline
\end{tabular}

Source: Authors' calculation from BankScope, using Stata 12

While the CR3 and CR5 are indicative of a pure market structure, they do not take into account the number of banks in the sector. The number of banks is closely related to competition and concentration. The HHI index will complement the not yet addressed aspect of the CR3 and CR5 indices by taking into account the number of banks in the sector and the relative size of banks. Table 2 presents the Herfindahl-Hirschman index for deposits, assets and loans of Vietnamese commercial banks in the period of 2005-2012. The indicators in Table 2 show the concentration of the banking sector during the study period. In general, in the period of 2005-2012, Vietnam's commercial banking sector was quite concentrated (HHI over 1,000), especially from the perspective of deposits and loans. However, it can be seen that the trend of concentration is decreasing for all three indicators. The HHI for deposits was 1671 in 2005 and dropped to 845 in 2012, in 8 years; HHI for assets 1662 in 2005 and decreased to 798 in 2012. Similarly, HHI for loans 2069 in 2005 and decreased to 1308 in 2012. In general, the rate of reduction HHI was quite strong in the period 2005-2012.

Table 2

Herfindahl-Hirschman of Vietnamese banking sector, 2005-2012

\begin{tabular}{|c|c|c|c|c|}
\hline \multirow[t]{2}{*}{ Year } & \multirow[t]{2}{*}{ Number of banks } & \multicolumn{3}{|c|}{ Herfindahl-Hirschman } \\
\hline & & Deposits & Assets & Loans \\
\hline 2005 & 27 & 1671 & 1662 & 2069 \\
\hline 2006 & 33 & 1501 & 1418 & 1716 \\
\hline 2007 & 35 & 1225 & 1039 & 1361 \\
\hline 2008 & 36 & 1268 & 1101 & 1414 \\
\hline 2009 & 43 & 950 & 838 & 1123 \\
\hline 2010 & 40 & 869 & 708 & 1030 \\
\hline 2011 & 38 & 858 & 703 & 1007 \\
\hline 2012 & 31 & 845 & 798 & 1008 \\
\hline Mean & & 1122 & 1002 & 1308 \\
\hline
\end{tabular}

Source: Authors' calculation from BankScope, using Stata 12

The HHI index has further strengthened the perception of the Vietnamese banking market in the period 2005-2012. That is: the Vietnamese banking market has changed from a moderate to high concentration market shown in HHI index from 1671 to 2069 to a non-centralized market with HHI between 798 and 1008.

\section{Empirical results and discussion}

We analyses concentration and competition of the Vietnamese banking industry between 2005 and 2012 . As it was mentioned before, the year 2005 is a milestone of Vietnamese banking system because of some important regulation decisions have been taken by the Vietnamese government.

\subsection{Concentration in the Vietnamese commercial banks}

\subsubsection{Statistical description}

Table 3 presents the descriptive statistics on the sample panel data of 2005-2012, including 44 commercial banks with total observations of 195. The mean value and standard deviation of the variables in Table 3 show that Vietnamese commercial banks are very diversified in terms of interest income, loan expenses, operating expenses, and total assets. The average net revenue from interests for the period of 2005-2012 of 44 banks was about USD 115 million (The bank with lowest volume was PetroVietnam Bank in 2005; the bank with highest volume was Agribank in 2011). The total loan expenses was about 231 million USD (The bank with the lowest volume was PetroVietnam Bank Group in 2005 and the bank with the highest volume 
was Agribank Bank in 2011), total operating expenses was about USD 6.6 billion (The bank with lowest operating expenses was PetroVietnam Bank in 2005 and the bank with the highest operating expenses was Agribank 2011), the ratio of loans to total assets was about 0.52 (The bank with the lowest ratio was Hong Leong Bank in 2010 and the bank with the highest ratio was Orient Commercial Bank in 2008). Equity on total assets was about 13.5 percent (The bank with the lowest ratio was Agribank in 2006 and the bank with the highest ratio was Hong Leong Bank in 2010), and the average total assets of banks was about 3.9 billion USD (The bank with the lowest total assets was Vietnam-Russia Bank in 2012 and the bank with the highest total assets was Agribank in 2010).

\section{Table 3}

Statistical description (model 3.1), 2005-2012

\begin{tabular}{|c|c|c|c|c|c|}
\hline Variable & Obs. & Mean & Std. & Min & Max \\
\hline Total interest income ('000 USD) & 195 & 115069 & 195704 & 271 & 1283239 \\
\hline Total loan costs ('000 USD) & 195 & 231308 & 374167 & 92 & 2424409 \\
\hline Total operating expenses ('000 USD) & 195 & 6601483 & 12000000 & 7415 & 79300000 \\
\hline Loans to total assets & 195 & 0.52 & 0.17 & 0.04 & 0.85 \\
\hline Equity to total assets & 195 & 13.48 & 11.28 & 1.08 & 94.29 \\
\hline Total assets ('000 USD) & 195 & 3881398 & 5578392 & 12789 & 28000000 \\
\hline
\end{tabular}

Source: Authors' calculation from BankScope, using Stata 12

Table 4 presents descriptive statistics of the variables in model 1 on the panel data sample. In general, ratio of loans to total assets, ratio of equity to total assets, and total assets change between years more than each year.

Table 4

Statistical description (model 3.1), 2005-2012

\begin{tabular}{|c|c|c|c|c|c|}
\hline Variable & & Mean & Std. & Min & Max \\
\hline \multirow[t]{3}{*}{ Total interest income ('000 USD) } & Total & 115069 & 195704 & 271 & 1283239 \\
\hline & Between year & & 152215 & 1420 & 839658 \\
\hline & Within year & & 83804 & -189443 & 567565 \\
\hline \multirow[t]{3}{*}{ Total loan costs ('000 USD) } & Total & 231308 & 374167 & 92 & 2424409 \\
\hline & Between year & & 287928 & 753 & 1641311 \\
\hline & Within year & & 181766 & -589784 & 1082429 \\
\hline \multirow[t]{3}{*}{ Total operating expenses ('000 USD) } & Total & 6601483 & 12000000 & 7415 & 79300000 \\
\hline & Between year & & 9578492 & 342626 & 57000000 \\
\hline & Within year & & 4584857 & -18000000 & 28900000 \\
\hline \multirow[t]{3}{*}{ Loans to total assets } & Total & 0.52 & 0.17 & 0.04 & 0.85 \\
\hline & Between year & & 0.16 & 0.12 & 0.81 \\
\hline & Within year & & 0.08 & 0.26 & 0.74 \\
\hline \multirow[t]{3}{*}{ Equity to total assets (\%) } & Total & 13.48 & 11.28 & 1.08 & 94.29 \\
\hline & Between year & & 12.76 & 3.38 & 80.73 \\
\hline & Within year & & 4.03 & 0.15 & 35.54 \\
\hline \multirow[t]{3}{*}{ Total assets ('000 USD) } & Total & 3881398 & 5578392 & 12789 & 28000000 \\
\hline & Between year & & 4464217 & 12789 & 23200000 \\
\hline & Within year & & 2067608 & -4499969 & 13500000 \\
\hline
\end{tabular}

$\mathrm{N}=195 ; \mathrm{n}=44 ; \mathrm{T}-\mathrm{bar}=4.43$

Source: Authors' calculation from BankScope, using Stata 12

\subsubsection{Empirical results}

As discussed, we conduct a regression analysis by using panel data to assess the concentration of banking sector in Vietnam (Model 1). In the following section, we discuss the regression analysis process, including steps and tests. The issue of outliers is potential in the dataset. In this study, we suspect outliers for the REVN variable in model 1. The results of test for potential outliers show that there exists one outlier in the sample. Therefore, we remove this observation from the sample to ensure that the research results are not biased due to the exceptional factor. The final sample includes 194 observations.

\subsubsection{Pooled OLS}

We regress the concentration model 1, using methods of Pooled OLS, FEM and REM after removing the outliers. We also examine the perfect multi-collinear phenomenon and the results show that some variables cause perfect multicollinearity (shown in the VIF value of this variable is greater than 10) such as: total assets (in logarithm form), total loan costs (in logarithm form), and total operating expenses (in logarithm form). Authors note this issue in the next regression steps. The authors further examine the unequal variance phenomenon in the model and the results show that there is an unequal variance phenomenon in model 3.1 (expressed in value of Chi- squared statistic (1) equal to 8.78 and p value equal to 0.0031 ). Authors then use the robust option in Stata's regression to correct the unequal variance phenomenon. Results of Pooled, FEM and REM are presented in Table 5. For Pooled OLS results in column 1 of Table 5, signs of control variables such as: total ratio of loans to total assets, ratio of equity to total assets, total $\log$ assets as expected and are statistically significant at the common levels. The most important result is the coefficient of the variable total loan expenses (in logarithm form) and total operating cost (in logarithm form). At the common level, the variable total cost of operation (in logarithm form) is positive and statistically significant at 
$1 \%$. In general, the sign of the variable total operating costs (in logarithm form) is similar to that in Gajurel and Pradhan (2012), Repková and Stavárek (2014). The statistical test $\mathrm{H}$ measures the market form, which shows the total statistical value $\mathrm{H}$ is equal to 0.486 for model 3.1, implying that the bank market in Vietnam is monopolistic competition.

\subsubsection{FEM}

In column 2 of Table 5, we present the FEM results and the results show that the variable total loan expenses (in logarithm form) is negative and statistically significant at $5 \%$, the variable total operating expenses (in logarithm form) is positive and statistically significant in $1 \%$ level. In general, the sign of the variable total operating costs (in logarithm form) is consistent with the pooled OLS regression results in column 1 and the same as the studies of Gajurel and Pradhan (2012), Repková and Stavárek (2014). Testing the model choice between the Pooled OLS model and the FEM model for Model 1 in Table 5 shows that the FEM model is superior to the Pooled OLS model. F statistic for null hypothesis is zero (the second bottom row of Table 5) is statistically significant at $1 \%$ means that the hypothesis that the $u$ components are at the same time equal to zero is rejected. This means that the fixed effect model is more appropriate. The statistical test $\mathrm{H}$ measures the market form, showing that the total value of $\mathrm{H}$ statistic is 0.724 and the t-test cannot reject this result at the common level of statistical significance, which implies the banking market in Vietnam is monopolistic competition.

\subsubsection{REM}

In column 3 of Table 5, we present the REM results and the results show that signs of control variables such as: total ratio of loans to total assets, ratio of total equity to total assets, total assets (logarithm form) are as expected and are statistically significant at common level.

\section{Table 5}

Competition model of Vietnamese commercial banks, 2005-2012

\begin{tabular}{|c|c|c|c|}
\hline \multirow[t]{2}{*}{ Variable } & $\begin{array}{c}\text { Total interest revenue }(\log ), \\
\text { Pooled OLS } \\
\end{array}$ & Total interest revenue $(\log )$, FEM & Total interest revenue (log), REM \\
\hline & $(1)$ & (2) & (3) \\
\hline Total interest expenses, $\log$ & $-0.063(1.04)$ & $-0.158(2.13)^{*}$ & $-0.092(1.62)$ \\
\hline Total other operating expenses, log & $0.549(7.74)^{* *}$ & $0.882(8.84)^{* *}$ & $0.647(9.72)^{* *}$ \\
\hline Ratio of loans to total assets & $0.606(3.88)^{* *}$ & $0.269(1.04)$ & $0.507(2.66)^{* *}$ \\
\hline Ratio of equity to total assets (\%) & $0.011(3.24)^{* *}$ & $-0.008(1.53)$ & $0.004(1.24)$ \\
\hline Total assets, $\log$ & $0.577(7.23)^{* *}$ & $0.346(3.35)^{* *}$ & $0.519(6.61)^{* *}$ \\
\hline \multirow{2}{*}{$\begin{array}{l}\text { Constant } \\
\mathrm{R}^{2}\end{array}$} & $-5.417(13.87)^{* *}$ & $-5.510(7.03)^{* *}$ & $-5.583(10.19)^{* *}$ \\
\hline & 0.95 & 0.87 & \\
\hline Observations & 194 & 194 & 194 \\
\hline H statistic & $\begin{array}{l}\text { (1) } \ln I N T C+\operatorname{lnNON} \text { INT_EXPENSE } \\
=0.486 \mathrm{~F}(1,188)=0.00 \\
\text { Prob }>\mathrm{F}=0.9991\end{array}$ & $\begin{array}{l}\text { (1) } \operatorname{lnINTC}+ \\
\text { lnNON_INT_EXPENSE }=0.724 \\
F(1,145)=0.00 \text { Prob }>F=0.9974\end{array}$ & $\begin{array}{l}\text { (1) } \operatorname{lnINTC}+ \\
\text { lnNON_INT_EXPENSE }=0.555 \\
\text { Chi2 } 2(1)=0.00 \text { Prob }>\text { Chi } 2=0.9977\end{array}$ \\
\hline \multicolumn{2}{|l|}{$\mathrm{F}$ test for $\mathrm{u}_{\mathrm{i}}=0$} & \multicolumn{2}{|l|}{$F(43,145)=4.36$ Prob $>F=0.0000$} \\
\hline Test: Ho: differ & rence in coefficients not systematic: chi & $5)=(b-B)^{\prime}\left[\left(V \_b-V \_B\right)^{\wedge}(-1)\right](b-B)=1$ & 26 Prob $>$ chi $2=$ \\
\hline
\end{tabular}

The variable total loan expenses (in logarithm form) has the negative sign and statistically significant at $5 \%$, the variable total cost of operation (in logarithm form) is positive and statistically significant at $1 \%$. In general, the sign of the variable total operating costs (in logarithm form) is consistent with the pooled OLS regression results in column 1, FEM in column 2 and the same as in Gajurel and Pradhan (2012), Repková and Stavárek (2014). Statistical tests H measure the market form, which shows that the total value of $\mathrm{H}$ statistic is 0.555 and the t-test cannot reject this result at the common level of statistical significance, which implies the banking market. in Vietnam is monopolistic competition. We use Hausman test to choose one of two models: the model using OLS with fixed effects (FEM) and the model using GLS with random effects (REM) with the hypothesis $\mathrm{H}_{0}$ : Estimators' difference between the two models is not significant. The testing results are shown in the bottom line of Table 5. Accordingly, the test statistic built by Hausman has an asymptotic distribution $\chi^{2}$ with degrees of freedom $(\mathrm{k}-1)$ equal to 5 (k: the parameter in the model). When the value of $\chi^{2}$ of the test model $(17,26)$ is less than the value of $\chi^{2}$ in the statistical table, and the probability is only 0,0040 , thus the hypothesis $\mathrm{H}_{0}$ is rejected and the FEM model is more appropriate.

\subsection{Effect of concentration on performance in the Vietnamese commercial banks}

\subsubsection{Statistic description}

Table 6 presents descriptive statistics on the 8-wave panel data sample of 37 commercial banks in 2005-2012 with the total number of observations is 168. The average value and standard deviation of the variables in Table 6 show that Vietnamese commercial banks very diverse in terms of interest income, total assets, market share of the bank's deposits, market share of total bank assets, market share of bank loans. The average net revenue from loan interest for the period of 2005-2012 of 37 banks is about 107.4 million USD. The ratio of loans to total assets is about 0.50 , the ratio of equity to total assets is about 13.5 percent, and the average total assets of banks is about 3.7 billion USD. The share of a bank's deposits, the share of its total assets, the share of its loans over the years is, on average, about $2 \%$ due to a relatively high level of market concentration. 
Table 6

Statistical description in model 3.2, 2005-2012

\begin{tabular}{|c|c|c|c|c|c|}
\hline Variable & Obs. & Mean & Std. & Min. & Max. \\
\hline Net interest revenue ('000 USD) & 168 & 107406.7 & 179490.2 & 271.0354 & 1283239 \\
\hline Loans to total assets & 168 & 0.4960 & 0.1687 & 0.0369 & 0.8370 \\
\hline Equity to total assets (\%) & 168 & 13.45 & 11.72 & 1.08 & 94.29 \\
\hline Total assets ('000 USD) & 168 & 3744358 & 5257056 & 14209.4 & 28000000 \\
\hline Share of the bank's deposits & 168 & 0.0016206 & 0.0029465 & 0.0000041 & 0.0158894 \\
\hline Share of the bank's total assets & 168 & 0.0015784 & 0.0025769 & 0.0000195 & 0.0150656 \\
\hline Share of the bank's loans & 168 & 0.0015228 & 0.0030945 & 0.0000033 & 0.0205056 \\
\hline
\end{tabular}

Source: Authors' calculation from BankScope, using Stata 12

Table 7 presents descriptive statistics of the variables in model 3.2 on the panel data sample. In general, the total revenue from loan interests, the ratio of loans to total assets, the ratio of equity to total assets, and total assets change between years more than each year.

Table 7

Statistical description in model 3.2, 2005-2012

\begin{tabular}{|c|c|c|c|c|c|}
\hline Variable & & Mean & Std. & Min. & Max. \\
\hline \multirow[t]{3}{*}{ Net interest revenue ('000 USD) } & Total & 107406.7 & 179490.2 & 271.0354 & 1283239 \\
\hline & Between year & & 147441.7 & 4474.674 & 839658 \\
\hline & Within year & & 67609.91 & -163396.2 & 550987.5 \\
\hline \multirow[t]{3}{*}{ Loans to total assets } & Total & 0.4960962 & 0.1687042 & 0.0369271 & 0.8369513 \\
\hline & Between year & & 0.156146 & 0.1222715 & 0.8024881 \\
\hline & Within year & & 0.0837179 & 0.2360211 & 0.7236003 \\
\hline \multirow[t]{3}{*}{ Equity to total assets (\%) } & Total & 13.45 & 11.72 & 1.08 & 94.29 \\
\hline & Between year & & 13.03 & 3.381667 & 80.73 \\
\hline & Within year & & 4.21 & 0.1125 & 35.51 \\
\hline \multirow[t]{3}{*}{ Total assets ('000 USD) } & Total & 3744358 & 5257056 & 14209.4 & 28000000 \\
\hline & Between year & & 4357482 & 201473.1 & 23200000 \\
\hline & Within year & & 1790130 & -4637009 & 9992144 \\
\hline \multirow[t]{3}{*}{ Share of a bank's deposits } & Total & 0.0016206 & 0.0029465 & 0.0000041 & 0.0158894 \\
\hline & Between year & & 0.0024542 & 0.0000169 & 0.0130614 \\
\hline & Within year & & 0.0008351 & -0.0023773 & 0.0070498 \\
\hline \multirow[t]{3}{*}{ Share of a bank's total assets } & Total & 0.0015784 & 0.0025769 & 0.0000195 & 0.0150656 \\
\hline & Between year & & 0.0021276 & 0.0000573 & 0.0112327 \\
\hline & Within year & & 0.0008132 & -0.0028414 & 0.0059651 \\
\hline \multirow[t]{3}{*}{ Share of a bank's loans } & Total & 0.0015228 & 0.0030945 & 0.0000033 & 0.0205056 \\
\hline & Between year & & 0.0026572 & 0.000014 & 0.0155135 \\
\hline & Within year & & 0.000724 & -0.0034578 & 0.0065149 \\
\hline
\end{tabular}

$\mathrm{N}=168 ; \mathrm{n}=37 ; \mathrm{T}-\mathrm{bar}=4.54$

Source: Authors' calculation from BankScope, using Stata 12

\subsubsection{Empirical results}

As discussed, we conduct a regression analysis by using panel data to assess the impact of market power on the operational performance of commercial banks in Vietnam (Model 2). In the following section, we discuss the regression analysis process, including steps and tests. The issue of outliers is potential in the dataset. In this study, we suspect outliers for the REVN variable in model 3.2. The results of test for potential outliers show that there exists one outlier in the sample. Therefore, we remove this observation from the sample to ensure that the research results are not biased due to the exceptional factor. The final sample includes 167 observations. Models 3.2A, 3.2B, and 3.2C are analyzed as follows:

- Step 1: Models 3.2A, 3.2B, and 3.2C are regressed, using the Pooled OLS method.

- Step 2: Test the multi-collinear phenomena in models 3.2A, 3.2B, and 3.2C is conducted. The results show that there is no perfect multicollinearity (expressed in the VIF value of the variables are smaller than 10).

- Step 3: Test results of unequal variance phenomenon in models 3.2A, 3.2B, and 3.2C is conducted. The results showed that unequal variance exists in models 3.2A, 3.2B, and 3.2C (probability values are all greater than 0.01 ).

- Step 4: The robust option in Stata's regression is used to adjust the unequal variance phenomenon.

Final regression results of models 3.2A, 3.2B, and 3.2C by Pooled OLS method are presented in Table 8. Signs of control variables such as: total ratio of loans to total assets, ratio of equity to total assets, total assets (in logarithm form) are as expected and are statistically significant at the common level. The most important results in Table 8 are the coefficients associated with the market concentration index such as HHI, CR3 and CR5. All HHI, CR3, and CR5 indices are as expected and: (1) The HHI deposits index is statistically significant at the 5\% level in model 3.2A, (2) CR5 is statistically significant at the 5\% level in the 3.2C model, (3) CR3 is statistically significant at the 5\% level in the 3.2B model. This result confirms the negative relationship hypothesis between the concentration of market concentration and operational performance of the banking sector in the context of the banking market being monopolistic competition (Bos, 2004). The group of variables related to the market share of 
deposits, assets, and loans has a positive sign as expected, the bank's share of deposits is statistically significant at $10 \%$, variables such as the bank's shares of assets and loans are not statistically significant.

Table 8

Effects of concentration on bank performance (Pooled OLS), 2005-2012

\begin{tabular}{|c|c|c|c|c|c|c|c|c|c|}
\hline \multirow{3}{*}{$\begin{array}{l}\text { Share of the bank's } \\
\text { deposits }\end{array}$} & \multicolumn{3}{|c|}{ Total interest income (log), Model 3.2A } & \multicolumn{3}{|c|}{ Total interest income $(\log )$, Model 3.2B } & \multicolumn{3}{|c|}{ Total interest income $(\log )$, Model 3.2C } \\
\hline & HHI deposits & HHI assets & HHI loans & CR3 deposits & CR3 assets & CR3 loans & CR5 deposits & CR5 assets & CR5 loans \\
\hline & $\begin{array}{l}20.78 \\
(1.75)^{*}\end{array}$ & & & $\begin{array}{l}22.31 \\
(1.89)^{*}\end{array}$ & & & $\begin{array}{l}20.12 \\
(1.69)^{*}\end{array}$ & & \\
\hline $\begin{array}{l}\text { Share of the bank's } \\
\text { assets }\end{array}$ & & $8.54(0.63)$ & & & $12.50(0.92)$ & & & $17.53(1.28)$ & \\
\hline $\begin{array}{l}\text { Share of the bank's } \\
\text { loans }\end{array}$ & & & $6.30(0.61)$ & & & $2.17(0.21)$ & & & $6.64(0.64)$ \\
\hline $\begin{array}{l}\text { Ratio of loans to } \\
\text { total assets }\end{array}$ & $\begin{array}{l}1.08 \\
(5.14)^{* * *}\end{array}$ & $\begin{array}{l}1.10 \\
(5.31)^{* * *}\end{array}$ & $\begin{array}{l}1.10 \\
(4.81)^{* * *} *\end{array}$ & $\begin{array}{l}1.08 \\
(5.20)^{* * *}\end{array}$ & $\begin{array}{l}1.10 \\
(5.36)^{* * *}\end{array}$ & $\begin{array}{l}1.10 \\
(4.82)^{* * *} *\end{array}$ & $\begin{array}{l}1.07 \\
(5.12)^{* * *}\end{array}$ & $\begin{array}{l}1.10 \\
(5.34)^{* * *} *\end{array}$ & $\begin{array}{l}1.09 \\
(4.79)^{* * *} *\end{array}$ \\
\hline $\begin{array}{l}\text { Ratio of equity to } \\
\text { total assets }\end{array}$ & $\begin{array}{l}0.02 \\
(4.73)^{* * *}\end{array}$ & $\begin{array}{l}0.02 \\
(4.98) * * *\end{array}$ & $\begin{array}{l}0.02 \\
(4.99) * * *\end{array}$ & $\begin{array}{l}0.02 \\
(4.71)^{* * *}\end{array}$ & $\begin{array}{l}0.02 \\
(4.96) * * *\end{array}$ & $\begin{array}{l}0.02 \\
(5.17)^{* * *} *\end{array}$ & $\begin{array}{l}0.02 \\
(4.73) * * *\end{array}$ & $\begin{array}{l}0.02 \\
(4.82) * * *\end{array}$ & $\begin{array}{l}0.02 \\
(5.00) * * *\end{array}$ \\
\hline $\begin{array}{l}\text { Total assets ('000 } \\
\text { USD), log }\end{array}$ & $\begin{array}{l}1.03 \\
(24.25)^{* * * *}\end{array}$ & $\begin{array}{l}1.06 \\
(24.09)^{* * * *}\end{array}$ & $\begin{array}{l}1.06 \\
(26.59)^{* * *}\end{array}$ & $\begin{array}{l}1.02 \\
(24.55)^{* * *}\end{array}$ & $\begin{array}{l}1.05 \\
(24.58)^{* * *}\end{array}$ & $\begin{array}{l}1.08 \\
(27.45)^{* * *}\end{array}$ & $\begin{array}{l}1.03 \\
(24.24)^{* * * *}\end{array}$ & $\begin{array}{l}1.04 \\
(23.84)^{* * * *}\end{array}$ & $\begin{array}{l}1.06 \\
(26.66)^{* * * *}\end{array}$ \\
\hline HHI deposits & $\begin{array}{l}-3.25 \\
(2.17)^{* *}\end{array}$ & & & & & & & & \\
\hline HHI assets & & $-1.34(1.02)$ & & & & & & & \\
\hline HHI loans & & & $-1.49(1.36)$ & & & & & & \\
\hline CR5 loans & & & & & & & & & $-0.69(1.40)$ \\
\hline CR5 assets & & & & & & & & $-0.75(1.78)^{*}$ & \\
\hline CR5 deposits & & & & & & & $\begin{array}{l}-0.96 \\
(2.12)^{* *}\end{array}$ & & \\
\hline CR3 loans & & & & & & $-0.37(0.65)$ & & & \\
\hline CR3 assets & & & & & $-0.66(1.40)$ & & & & \\
\hline CR3 deposits & & & & $\begin{array}{l}-1.32 \\
(2.33)^{* *}\end{array}$ & & & & & \\
\hline Number of obs. & 167 & 167 & 167 & 167 & 167 & 167 & 167 & 167 & 167 \\
\hline $\mathrm{R}^{2}$ & 0.92 & 0.91 & 0.91 & 0.92 & 0.92 & 0.91 & 0.92 & 0.92 & 0.92 \\
\hline
\end{tabular}

\section{Conclusions and implication}

The current paper has used a quantitative model with a data set of 44 banks collected from Bankscope, from 2005 to 2012 including 195 observations for the market power regression analysis in Vietnamese banking sector and for analysis the effect of market power on the operational performance of commercial banks in the period of 2005-2012. The results of the competitive analysis have shown that a status of monopoly competition market has formed in the banking sector. The statistical test $\mathrm{H}$ measures the market form, showing that the total statistical value $\mathrm{H}$ is equal to 0.54 (The t-test cannot reject this result at the level of common statistical significance). In general, a decrease of the concentration indicators goes hand in hand with increase in competition in the Vietnam 's banking sector over the analyzed period. The results of in-depth analysis of the influence of market power on the operational performance of commercial banks in Vietnam with an adjustment to eliminate the heteroskedasticity confirms a negative relationship between the concentration of the market and operational performance of commercial banks in the context of monopoly competition. In result, high competition and less concentration enable the banking sector to achieve a more balanced allocation of credits and contributing to sustainable economic growth.

\section{References}

Bikker, J. A., \& Haaf, K. (2002). Competition, concentration and their relationship: An empirical analysis of the banking industry. Journal of Banking \& Finance, 26(11), 2191-2214.

Bos, J. W. (2004). Does market power affect performance in the Dutch banking market? A comparison of reduced form market structure models. De Economist, 152(4), 491-512.

Gajurel, D. P., \& Pradhan, R. S. (2012). Concentration and competition in Nepalese banking. Journal of Business, Economics, $1(1), 5-16$.

Klein, M. A. (1971). A theory of the banking firm. Journal of money, credit and banking, 3(2), 205-218.

Molyneux, P., Altunbas, Y., \& Gardener, E. (1997). Efficiency in European Banking. New York: John Wiley and Sons.

Repková, I., \& Stavárek, D. (2014). Concentration and competition in the banking sector of Turkey. Amfiteatru Economic, $16(36), 625$.

Salop, S. C. (1979). Monopolistic competition with outside goods. The Bell Journal of Economics, 10(1), $141-156$.

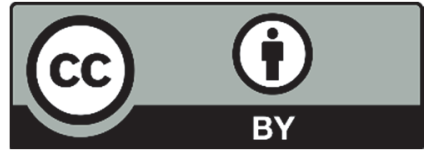

(C) 2019 by the authors; licensee Growing Science, Canada. This is an open access article distributed under the terms and conditions of the Creative Commons Attribution (CC-BY) license (http://creativecommons.org/licenses/by/4.0/). 